\title{
W sieci. Powojenne polskie siatki wywiadowcze (AK-NIE-WiN, PSZ) w latach 1944-1955, red. M. Bachta, Wyd. IPN - Komisja Ścigania Zbrodni przeciwko Narodowi Polskiemu, Warszawa 2016, ss. 502
}

Podziemie antykomunistyczne w Polsce było bezpośrednią kontynuacją organizacyjną i ideową konspiracji działającej na terenie kraju w okresie drugiej wojny światowej. W historiografii rozpowszechniony jest podział na podziemie ,antykomunistyczne” - ,antysowieckie” oraz „,antynazistowskie” - „antyniemieckie”, jednak w większości przypadków kryterium tego podziału nie stanowią założenia programowe, ale układ chronologiczny i geograficzny. $Z$ tej przyczyny podziemie działające w latach 1941-1944 uznawane jest za antyniemieckie, a późniejsze za antykomunistyczne (Niwiński 2005: 13).

Od pierwszych chwil tworzenia organów bezpieczeństwa publicznego PPR w resorcie bezpieczeństwa widziała swojego naturalnego sojusznika, przy pomocy którego przejmie władzę. W ocenie władz PPR taki układ polityczny podparty siłą sprawczą bezpieki gwarantował przejęcie władzy, skuteczną walkę z politycznym przeciwnikiem, a dzięki współpracy $\mathrm{z}$ organami bezpieczeństwa dawał również możliwość dostępu do informacji (APRz 118,2,P-7103:11).

Organa bezpieczeństwa w Polsce Ludowej pełniły jedną z kluczowych ról w zakresie instalowania władzy komunistycznej, jej utrwalania i budowy systemu represji. $\mathrm{W}$ istocie aparat bezpieczeństwa został utworzony przez komunistów do budowy ustanowionej przez nich wła-

${ }^{1}$ Dr Arkadiusz Machniak reprezentuje Regionalne Towarzystwo Naukowe w Przeworsku, pracownik Wojska Polskiego, e-mail: amur5@tlen.pl 
dzy. Organa władzy komunistycznej w Polsce - podobnie jak w innych krajach poddanych dominacji sowieckiej, których podstawowym zadaniem była ochrona interesów władzy komunistycznej - zostały utworzone na wzór i przy bardzo fundamentalnym wsparciu ZSRR (Iwaneczko 2004: 9).

Instytut Pamięci Narodowej w 2016 r. wydał publikację pod redakcją naukową Mariusza Bachty poświęconą losom powojennych siatek wywiadowczych i kontrwywiadowczych działających na terenie Polski w latach 1944-1955. Jest to niewątpliwie pozycja wypełniająca lukę w badaniach naukowych związanych z polskim wywiadem i kontrwywiadem jako formacjami nawiązującymi do tradycji II RP i Oddziału II Sztabu Generalnego Wojska Polskiego z lat 1918-1939 oraz 19391944/45. Recenzowana książka charakteryzuje siatki wywiadowcze działające na terenie ziem polskim pod reżimem komunistycznym w opisanej cenzurze czasowej.

Praca składa się ze wstępu, dziewięciu artykułów, wykazu skrótów, indeksu osób i nazw geograficznych. Wzbogacana została obszernym i wartościowym materiałem fotograficznym. Nie mam uwag i zastrzeżeń co do wykorzystanych materiałów źródłowych i opracowań. Autorzy poszczególnych tekstów jasno określili cele badawcze swoich publikacji.

Opracowanie otwiera artykut, którego autorami są Mariusz Bachta i Agnieszka Chrzanowska. Zatytułowany został: Działalność ekspozytur wywiadu wschodniego AK, DZS i II Korpusu Polskiego - krypt. „, Pralnia II”, „Port”, „Liceum” w latach 1944-1946. W tekście została przedstawiona geneza siatki wywiadowczej „Liceum” i jej kolejnych mutacji wywodzących się z Referatu Wschód Wydziału Ofensywnego KG ZWZ-AK powstałej w połowie 1941 r. po agresji Niemiec faszystowskich na Związek Sowiecki. Istotnym wątkiem w tym materiale jest charakterystyka przedmiotowych siatek wywiadowczych działających po połowie 1944 r., to jest w okresie wkroczenia na teren okupowanych ziem polskich Armii Czerwonej i instalowania w kraju władzy komunistycznej. Autorzy przeanalizowali działalność struktur siatek wywiadowczych, o których w powszechnej świadomości niewiele wiadomo. Jest to zatem materiał pionierski. W artykule scharakteryzowano kierunki i cele działania siatek wywiadowczych, stosowane metody pracy operacyjnej, kadry, łączność. Tekst zamyka opis rozpracowania siatek wywiadowczych przez komunistyczny aparat bezpieczeństwa i proces ich członków. Praca została wzbogacona materiałem fotograficznym, dokumentami źródłowymi dotyczącymi struktur organizacji, instrukcji, meldunków wywiadowczych i kontrwywiadowczych. 
Drugim artykułem jest tekst Piotra Niwińskiego pt. Wywiad Okręgu Wileńskiego AK po lipcu 1944 roku. Autor poddał ocenie działalność struktur wywiadu na Wileńszczyźnie w trzech etapach: pierwszy dotyczy okresu od lipca 1944 do lipca 1945, kolejny od sierpnia 1945 do kwietnia 1946, a ostatni jest związany z okresem od marca 1947 do czerwca 1948. Przez te trzy fazy autor ukazuje sukcesywne rozbicie okręgu przez NKWD, wzrost represji ze strony Urzędu Bezpieczeństwa i próbę przeprowadzenia „Akcji X”. Słusznie zauważa, iż siatka wywiadu Okręgu Wileńskiego AK w zmienionych realiach geopolitycznych po 1945 r. tak naprawdę stała się częściowo siatką o profilu informacyjnym i na poły amatorską, co umożliwiło aparatowi represji jej rozpracowanie i likwidację. Na uwagę zasługuje postać por. Zygmunta Szymanowskiego ps. „Beza”, który kierował w sposób wyjątkowo skuteczny jedną z siatek wywiadowczych. Ponadto jego postawa w trakcie śledztwa, jak udowadnia P. Niwiński, skutecznie uniemożliwiła aresztowanie przez UB innych członków siatki wywiadowczej. Do tekstu dołączone zostały dwa wybrane materiały źródłowe w postaci raportów wywiadowczych wywiadu Okręgu Wileńskiego AK.

Tomasz Łabuszewski jest autorem trzeciego tekstu, zatytułowanego Siatki wywiadowcze Obszaru Centralnego DSZ-WiN. Przedstawił w nim genezę formowania struktur wywiadowczych Obszaru Centralnego Delegatury Sił Zbrojnych na Kraj kształtujących się wiosną 1945 r. Moją uwagę w tym tekście zwróciły informacje o rozpracowywaniu tej siatki wywiadowczej przez komunistyczne podziemie, reprezentowane w tym względzie przez Włodzimierza Lechowicza, Barbarę Sowińską i Mariana Spychalskiego. Paradoksem okazało się, że kilka lat później B. Sowińska, jako Szef Biura Studiów GZI WP, poniosła z tego tytułu konsekwencje z pobytem w więzieniu włącznie. Tekst klarowanie przedstawia zakres działań sieci wywiadowczej, personalia osób z podziemia i zakres ich działania. Siatka ta cechowała się dużą dynamika rozwoju, lecz w praktyce, jak udowadnia autor tekstu, okazała się strukturą krótkotrwała. Po jej dekompozycji zadania realizowane były w ramach siatki wywiadowczej Obszaru Centralnego WiN. Również i ta struktura okazała się efemerydą, została bowiem rozbita w lutym 1946 r. Represje, jakie przeprowadzał komunistyczny aparat bezpieczeństwa od jesieni 1946 do początku stycznia 1947 r., spowodowały paraliż siatek wywiadowczych WiN w tym regionie, a także rozbicie powiązanych z nim obszarów łódzkiego i białostockiego. Do tekstu dołączony został wybrany materiał źródłowy w postaci raportu wywiadowczego.

Czwarty artykut, pióra Kazimierz Krajewskiego pt. Siatki wywiadowcze Obszaru Południowego działajacego na terenie Obszaru Cen- 
tralnego Zrzeszenia WiN bardzo logicznie komponuje się z rozdziałem wcześniejszym. Należy zaznaczyć, zgodnie zresztą z uwagą K. Krajewskiego, iż struktura wywiadowcza Zrzeszenia WiN była złożona. Część jej agend przekształcona została z DSZ, inne budowano od podstaw. Krajewski skupił się w swoim tekście na Zarządzie Obszaru Południowego Zrzeszenia WiN. Przedstawia w układzie chronologicznym od jesieni 1945 r. początki działalności wywiadu tej struktury WiN: najpierw siatki wywiadu krypt. „Filia-I”, następnie „Montownia”, „Syrena-Wisła”, jak również opisuje losy kilku pomniejszych siatek podległych głównym strukturom, mających jednak dość ograniczone znaczenie.

Likwidacja w 1947 r. przez MBP IV Komendy WiN była początkiem powolnej agonii siatek wywiadowczych, aczkolwiek jeszcze nie zatrzymała ich działalności. Dopiero na początku 1948 r. UB skutecznie zneutralizował działalność siatek wywiadowczych Obszaru Południowego WiN. Słusznie zauważa autor, iż ci, którzy zostali przewerbowani przez aparat bezpieczeństwa, stanęli wkrótce przeciwko swoim dawnym towarzyszom z podziemia i wywiadu, tworząc jedną z największych i w dodatku wyjątkowo skuteczną prowokację MBP w postaci V Komendy WiN. Tekst godny uwagi i dobrze wprowadzający do następnego artykułu.

Kolejny artykuł zatytułowany Siatki wywiadowcze Obszaru Południowego Zrzeszenia „Wolności i Niezawistość”, którego autorem jest Wojciech Frazik, przedstawia koncepcję realizowaną przez WiN nie na płaszczyźnie walki zbrojnej, ale w formie walki politycznej. Słusznie wskazał jego autor, że tworzenie siatek wywiadowczych na tym terenie było uwarunkowane losami konspiracji poakowskiej. Celem działalności siatek wywiadowczych była ochrona własnych struktur przed działalnością NKGB, NKWD, WUBP, MO i PPR, co wskazywało, kto był naturalnym przeciwnikiem $\mathrm{W}$ walce informacyjnej. Warto polecić epizod w tym tekście dotyczący akcji „Z Ż”, polegającej na rozpoznawaniu składu narodowościowego jednostek wojskowych i ich morale oraz roli, jaką w tym zakresie odegrał mjr Łukasz Ciepliński. Polecam kolejne wartościowe informacje dotyczące m.in. działalności Brygad Wywiadowczych rozpoznających wszystkie agendy władzy komunistycznej w Polsce oraz siatki krypt. „Stomil-Iskra” powołanej przez mjra Ł. Cieplińskiego. Siatka ta sporządzała comiesięczne sprawozdania informacyjne, głównie na podstawie raportów sieci informatorów w terenie.

Autor logicznie udowadnia, że istnienie struktur informacyjnych było jednym $\mathrm{z}$ warunków skutecznego funkcjonowania konspiracji niepodległościowej. Jako pewien sukces Zrzeszenia WiN należy postrzegać uplasowanie własnej sieci agentury we wszystkich niemal strukturach 
nowej władzy w Polsce, w tym w komunistycznym aparacie represji. Podobnie jak w przypadku wcześniejszych tekstów do artykułu dołączone zostały materiały źródłowe.

Bogdan Chrzanowski jest autorem szóstego w kolejności tekstu, pt. Siatki wywiadowcze Okręgu Pomorskiego AK-Nie-DSZ-WiN. Tekst przedstawia genezę i rozwój siatek wywiadowczych wymienionych organizacji od początku 1945 r., czyli jeszcze w okresie okupacji niemieckiej i schyłkowym okresie II wojny światowej, aż do aresztowań przez aparat bezpieczeństwa w 1949 r. Autor wskazuje na uwarunkowania towarzyszące powstawaniu niepodległościowych siatek wywiadowczych, personalia działaczy oraz główne kierunki działań. Przedsięwzięcia realizowane przez UB, w tym wykorzystywanie niekiedy dawnych agentów służb niemieckich (gestapo), skutecznie doprowadziły do rozpracowania siatek wywiadowczych i ich dekompozycji. Autor mógł w tym miejscu pokusić się o załączenie większej ilości materiałów źródłowych obrazujących ich działalność. Nie jest to jednak ujmą dla całego tekstu.

Agnieszka Łuczak swoje rozważania w tekście zatytułowanym Siatki wywiadowcze Wielkopolskiej Samodzielnej Grupy Ochotniczej „Warta" poświęciła strukturom wywiadu podziemia antykomunistycznego w Wielkopolsce. Analizuje działalność tych struktur na przykładzie największej organizacji antykomunistycznej w tym regionie, jaką była Wielkopolska Samodzielna Grupa Ochotnicza „Warta”. W artykule przedstawiony został obraz struktur i ich obsada personalna, omówiono działalność komórek wywiadu, kontrwywiadu, żandarmerii. Ponownie jako jedne $\mathrm{z}$ ciekawszych przywołuję $\mathrm{w}$ tym miejscu informacje dotyczące akcji „Ż”. A. Łuczak logiczne wskazuje, że działalność siatek wywiadowczych w tym regionie cechowała się inną wizją metodyki postępowania i kierunków zainteresowań, oraz uwypukla najbardziej intensywny okres ich działania: czerwiec - wrzesień 1945 r. Wartościowym załącznikiem do tekstu są materiały źródłowe w postaci sprawozdań.

Ósmy tekst napisany został przez Aleksandra Kozickiego, nosi tytuł Struktury organizacyjne i formy pracy emigracyjnego wywiadu wojskowego w latach 1945-1955 (wybrane przyklady). Na wstępie A. Kozicki słusznie wskazuje na marginalny zakres zainteresowań działalnością polskiego wywiadu wojskowego po zakończeniu II wojny światowej w porównaniu z publikacjami, które obrazują jego działalność w okresie II Rzeczypospolitej. Wnioskuję, że intencją Kozickiego było podjęcie dyskusji naukowej w przedmiotowym zagadnieniu. W ramach wyznaczonych standardami artykułu wywiązał się z tego zadania bardzo dobrze. Poruszył kilka wątków. W pierwszym opisuje działalność Oddziału Informacyjno-Wywiadowczego 2 Korpusu działającego w latach 1945- 
1946. Drugim wątkiem są informacje dotyczące tzw. Biura Planowania. Trzecim i ostatnim wątkiem są działania polskiego wywiadu na terenie Austrii w latach 1950-1955. Praca jest zwięzła i w klarowny sposób przedstawia struktury wywiadu wojskowego oraz formy jego działania. Działalność wywiadu wojskowego w tym okresie należy postrzegać w znaczeniu strategicznym, biorąc pod uwagę jego aktywność w określonych regionach świata. Kozicki swoim artykułem wykazał, jaki był charakter działań tej służby po II wojnie światowej w imię dobra Rzeczypospolitej. Do tekstu dołączone zostały materiały źródłowe wskazujące charakter informacji pozyskiwanych przez polski wywiad wojskowy.

Zbiór tekstów w recenzowanej książce zamyka pozycja Patryka Pleskota pt. Czerwony Kontrwywiad. Struktura Departamentu I MBP 1944 1954 (pion centralny). Moje główne zastrzeżenie do tego tekstu jest takie, iż nie rozumiem, dlaczego został umieszczony w monografii poświęconej polskim siatkom niepodległościowym wywiadu i kontrwywiadu w latach 1944-1955. Gdyby jeszcze autor skupił się na przeanalizowaniu wybranych wątków działalności Departamentu I MBP w kontekście jego walki z podziemiem niepodległościowym, jego przesłanki byłyby jasne. W przedstawionym jego kształcie nie widzę wspólnego mianownika z pozostałymi tekstami i uważam, że pomimo jego walorów naukowych nie powinien być publikowany w recenzowanej monografii. Praca kwalifikuje się np. do rocznika „Aparat represji w Polsce Ludowej w latach 1944-1989”. Pleskot analizuje przekształcenia strukturalne i zmiany personalne w Departamencie I MBP. W artykule aż roi się od wyrazów takich jak wydział, sekcja, zmiany, reforma etc. Tekst jest jednak nudny. I tylko dla wyjątkowo wytrwałych.

Recenzowana książka jest zbiorem studiów merytorycznie wypełniających jej tytułową problematykę (z wyjątkiem tekstu Pleskota). Dobrze wpisuje się w modny ostatnio nurt badań naukowych nad polskim podziemiem niepodległościowym w latach 1944-1956. Moim zdaniem otwiera szerokie pole do badań związanych z polskim wywiadem i kontrwywiadem. Warto $w$ tym miejscu zaznaczyć, że jest to również okazja do ukazania niezłomnych postaw patriotycznych osób walczących w imię dobra Rzeczypospolitej.

Lektura życiorysów tych wszystkich, którym w wywiadzie i kontrwywiadzie powierzono funkcje kierownicze, przekonuje, że najliczniejszą grupę stanowili w tych służbach oficerowie mający za sobą doświadczenia strzeleckie, a następnie legionowe. Do służb specjalnych nie kierowano osób przypadkowych, a ich ideowa postawa była bez wątpienia liczącym się elementem rekrutacji. Trudno nie dostrzec, że kierowniczy trzon służb specjalnych II Rzeczypospolitej stanowili ci, którzy wyrasta- 
jąc w ideowej, patriotycznej atmosferze ruchu paramilitarnego stworzonego przede wszystkim przez Józefa Piłsudskiego, dostrzegali realną szansę na wyruszenie z bronią w ręku do jawnej, otwartej walki o Polskę. Związek Sowiecki pozostawał dla nich wrogiem głównym, zagradzającym drogę do niepodległości (Suleja 2013:11-12).

Aby skutecznie uzyskiwać ciekawe informacje wywiadowcze i kontrwywiadowcze, należało podejmować wiele skomplikowanych czynności oraz żmudnych przedsięwzięć. Praca wywiadowcy dzieliła się na dwa etapy: właściwą - wywiadowczo-rozpoznawczą mającą dostarczyć wszelkich danych do planowanych akcji oraz końcową. Skuteczność pracy wywiadowczej uzależniona była od dobrze przeprowadzonych obserwacji oraz odpowiedniego zachowania się wywiadowcy (Kunicki 1969: 173).

Należy zgodzić się z teorią przedstawioną przez Władysława Bułhaka i Andrzeja K. Kunerta. Twierdzą oni mianowicie, że kontrwywiad, czyli wywiad defensywny polskiej konspiracji czasów ostatniej wojny i okupacji przez bardzo długi czas był pomijany w literaturze historycznej niemal całkowitym milczeniem (Bułhak, Kunert 2008: 6). Recenzowana praca $\mathrm{w}$ istotny sposób uzupełnia wiedzę dotyczącą polskich służb wywiadu i kontrwywiadu w latach 1944-1956.

Nie tylko historycy ulegają czasami magii wywiadu i kontrwywiadu. Często staje się to również udziałem polityków. Premier rządu angielskiego Winston Churchill dosadnie oceniał działalność służb, mówiąc, iż „na najwyższym poziomie pracy tajnych służb $\mathrm{w}$ wielu przypadkach autentyczne wydarzenia były w każdym względzie równe najbardziej fantastycznym pomysłom $\mathrm{z}$ romansów czy melodramatów, intryga w intrydze, spisek i przeciwdziałanie, fortel i zdrada, podstęp i oszustwo, prawdziwy agent, fałszywy agent, podwójny agent" (Brown 1997: 20).

Recenzowana książka nie jest pozycją przeznaczoną dla pasjonatów służb specjalnych postrzegających wywiad i kontrwywiad poprzez pryzmat ukazujących się na rynku wydawniczym książek autorstwa Vincenta V. Severskiego. Jest publikacją naukową rzetelnie i obiektywne ukazującą działalność określonych struktur podziemia antykomunistycznego walczącego z narzuconym narodowi polskiemu nowym ustrojem komunistycznym, wyrażam nadzieję, iż nie ostatnią fachową publikacją poświęconą dziejom polskiego wywiadu i kontrwywiadu.

\section{Literatura}

\section{Materiały źródłowe}

Archiwum Państwowe w Rzeszowie, zespół nr 1118, sygn. 2, P-7103, Protokół z posiedzenia KP PPR w Przeworsku z dnia 23 IX 1945 r. 


\section{Opracowania}

Brown C.A., 1997, W stużbie klamstwa. Wojna szpiegów, Warszawa.

Bułhak W., Kunert K.A., 2008, Kontrwywiad podziemnej Warszawy. Struktura, zadania i obsada personalna kontrwywiadu Komendy Gtównej, Obszaru Warszawa i Okręgu Warszawa ZWZ-AK w latach 1939-1944 [w] Wywiad i Kontrwywiad Armii Krajowej, red. W. Bułhak, Warszawa.

Iwaneczko D., 2004, UBP w Przemyślu 1944-1956, Rzeszów.

Kunicki A., 1969, Cichy front. Ze wspomnień oficera wywiadu dywersyjnego dyspozycyjnych oddziałów Kedywu KG AK, Warszawa.

Niwiński P., 2005, Aparat represji a opór społeczny wobec systemu komunistycznego w Polsce i na Litwie w latach 1944-1956, Warszawa.

Suleja W., 2013, Stużby specjalne II Rzeczypospolitej. Ideowy rodowód [w:] Kontrwywiad II RP (1914) 1918 - 1945 (1948), t. I, red. Z. Nawrocki, Warszawa. 